Ilona Florczak

(Uniwersytet Łódzki

Wydział Filozoficzno-Historyczny

Katedra Historii Historiografii i Nauk Pomocniczych Historii)

\title{
ŹRÓDLA DO DZIEJÓW PODLASIA W ARCHIWUM RODZINY BARTOSZEWICZÓW
}

W spomniane w tytule Archiwum rodziny Bartoszewiczów jest przechowywane w Archiwum Państwowym w Łodzi (dalej APL). Na jego zasób składają się zbiory gromadzone przez cztery pokolenia. Inicjatorem pasji zbierackiej, tak powszechnej w XIX wieku, był Adam Bartoszewicz (1792-1878) ${ }^{1}$, a podzielali ją i kontynuowali jego potomkowie - syn Julian (1821-1870) i wnuk Kazimierz (1852-1930)². W jej wyniku powstał bogaty zbiór materiałów archiwalnych różnorodnych zarówno pod względem treści jak i formy. Historycy często sięgają po przechowywane w archiwum materiały, wydaje się jednak, że potencjał badawczy zgromadzonych akt nie został jeszcze w pełni wykorzystany. Wśród zachowanych materiałów archiwalnych odnaleźć można wiele materiałów do dziejów Podlasia ${ }^{3}$. Ze względu na duże rozproszenie źródeł wytworzonych na omawianym terytorium warto przybliżyć te, które zachowały się w archiwum rodziny Bartoszewiczów. Gromadzone przez lata zbiory, Kazimierz Bartoszewicz, wobec braku spadkobiercy, zdecydował się przekazać Magistratowi Miasta Łodzi. Kolekcja, na którą składały się nie tylko cenne rękopisy, ale także bogaty księgozbiór i zbiór obrazów, miała pozostać nierozerwalną całością, sygnowaną nazwiskiem rodziny. Stało się jednak inaczej - zbiory zostały podzielone pomiędzy różne instytucje - archiwalia trafiły

${ }^{1}$ Data urodzin jest trudna do ustalenia - w źródłach autobiograficznych Bartoszewicz podawał różne dwie daty - 1792-1794. Archiwum Państwowe w Łodzi (dalej: APŁ), Archiwum Rodziny Bartoszewiczów (dalej: Archiwum Bartoszewiczów), sygn. 734, k. 2,17. Wnuk Adama Bartoszewicza, w pracach poświęconych dziadkowi wymieniał datę 1792 r. K. Bartoszewicz, Silva rerum Adama Bartoszewicza [Kraków 1912 - przedruk z „Przeglądu Narodowego”], s. 237.

${ }^{2}$ Częścią archiwum są też materiały pozostawione przez synów Kazimierza Juliana Adama Kantego (1883-1926) i Kazimierza Władysława (1885-1919) - I. Ugorowicz, Z Krakowa do Łodzi. Dzieje i zawartość Archiwum rodziny Bartoszewiczów, „Rocznik Łódzki”, t. 60, 2013, s. 187-188.

${ }^{3}$ Termin Podlasie odnoszę zarówno do ziem województwa podlaskiego z okresu I Rzeczypospolitej, jak i do ziem, które stały się częścią województwa podlaskiego, a następnie guberni podlaskiej w okresie rozbiorów. Ze względu na dużą rozpiętość chronologiczną i tematyczną niniejszy szkic ma charakter przeglądowy, nie zaś wyczerpujący. 
do Archiwum Państwowego, książki do Miejskiej Biblioteki Publicznej, a dzieła sztuki do Muzeum Sztuki ${ }^{4}$. Opisywane niżej archiwum zostało uporządkowane, powstał również inwentarz zespołu, wraz z indeksem osobowym i geograficznym.

\section{Twórcy archiwum i ich związki z Podlasiem}

Adam Mateusz Bartoszewicz urodził się w majątku Świrny w powiecie wiłkomirskim w 1792 r. Początkowo nauki pobierał w domu, następnie uczył się w prowadzonej przez bernardynów szkole w Traszkunach. Po jej ukończeniu rozpoczął naukę w Cesarskim Uniwersytecie Wileńskim, jednym z najlepszych, w owym czasie, uniwersytetów we wschodniej Europie. W 1812 r. wraz z innymi studentami Akademii Wileńskiej „wkroczył w szeregi powstańców”, czyli wziął udział w wielkiej wyprawie Napoleona na Rosję. Po klęsce wojsk napoleońskich ukrywał się przez jakiś czas, a następnie, po ogłoszeniu amnestii dokończył studia i zgłosił się do pracy w oświacie, przyjmując posadę w szkole w Mirosławiu5. W 1816 r., po zdaniu egzaminu rządowego, rozpoczął służbę państwową jako nauczyciel w Białej Radziwiłłowskiej (Podlaskiej). W mieście pozostał do 1833 r. Tutaj na Podlasiu, jak pisał jego wnuk w przedmowie do wydanych drukiem wspomnień dziadka, „spędził najpiękniejsze lata swego życia”. W czasie, który spędził w Białej Podlaskiej, założył rodzinę - jego żoną została siostra Józefa Zentgellera (Sentgellera), kolegi z grona profesorskiego szkoły bialskiej, Amelia. Tutaj też urodziły się kolejne dzieci Bartoszewiczów - jako pierwszy na świat przyszedł Julian, a kolejnych latach na świat przyszło czworo dzieci Wraz z rodziną mieszkał nieopodal szkoły, i podobnie jak inni profesorowie, aby podratować budżet rodzinny, przyjmował uczniów na stancję ${ }^{8}$. Rozrastająca się rodzina, a także przejęcie opieki nad dziećmi zmarłego przedwcześnie szwagra (mowa tu o synach Józefa Zentgellera) wpływała na sytuację materialną rodziny.

\footnotetext{
${ }^{4}$ Szerzej: I. Ugorowicz, Z Krakowa do Łodzi..., s. 189-191; A. Rosenberg, Zbiory rękopiśmienne Miejskiego Muzeum Historii i Sztuki im. J. i K. Bartoszewiczów w Łodzi, „Dziennik Zarządu miasta Łodzi" 1938 , nr 1, s. 23-30, nr 2, s. 154-169.

${ }^{5}$ Informację tę podaję za notką biograficzną umieszczoną w wydanych w 1812 r. wspomnieniach Adama Bartoszewicza (K. Bartoszewicz,.Dawna Biała na Podlasiu we wspomnieniach mego dziadka Adama (1792-1878). Przyczynek do dziejów miasta i gimnazjum, Biała Podlaska 1928, s. 3). Warto w tym miejscu zaznaczyć, że Adam Bartoszewicz nie wspominał o swoim czynnym udziale w wydarzeniach 1812 r. - ten epizod ze swojego życia pomijał, zwłaszcza w pozostawionych wspomnieniach i aktach osobowych kierowanych do władz zwierzchnich. APŁ, Archiwum Bartoszewiczów, sygn. 749, k. 1-2.

${ }^{6}$ K. Bartoszewicz, Dawna Biała..., s. 4.

${ }^{7}$ Julian Bartoszewicz miał dwie siostry - Klementynę i Józefę i dwóch braci - Zygmunta i Adama Antoniego.

${ }^{8}$, ,W podwórzu Akademii na prawo, tyłem do ulicy zamkowej stał drewniany dworek - pisał Jan Gloger - w którym mieszkał profesor Adam Bartoszewicz. J. Gloger, Szkoła bialska i czteroletni w niej pobyt J.I. Kraszewskiego <1822-1826>. Wspomnienie kolegi szkolnego, Biała Podlaska 1928, s. 6.
} 
Niewielka pensja nauczycielska z trudem zaspokajała potrzeby rodziny, mimo to młody profesor lubił swoją pracę, wykonywał ją sumiennie i z zaangażowaniem. Był cenionym przez uczniów wykładowcą, znanym w środowisku kolekcjonerem pamiątek przeszłości i początkującym paremiografem. Wielokrotnie w literaturze przedmiotu podkreślano, że był pierwszym mentorem Józefa Ignacego Kraszewskiego, w którym obudził zainteresowania historią i literaturą polską ${ }^{9}$ W Białej przeszedł kolejne szczeble kariery nauczycielskiej, a profesorem został w $1827 \mathrm{r}$. Pełnił także funkcję Marszałka Zgromadzenia Gminnego okręgu obejmującego powiat bialski i łosicki. Wybór Bartoszewicza do pełnienia tej funkcji świadczył o tym, że był on znany w lokalnym środowisku, ale też, że był szanowanym obywatelem o nienagannej postawie wobec władz zwierzchnich. Profesor opuścił Białą Podlaską już po zakończeniu powstania listopadowego - warto nadmienić, że nie brał w nim udziału i, w późniejszym okresie dystansował się wobec wydarzeń tego okresu ${ }^{10}$. Na krótki okres został skierowany do pracy w szkole w Warszawie, a następnie został umieszczony w szkole w Łukowie, by znów, po roku, powrócić tym razem już na stałe do stolicy Królestwa Polskiego. Awansował wówczas na stanowisko inspektora szkół obwodowych - funkcję tę pełnił do 1850 r., czyli do momentu zwolnienia ze służby państwowej i przejścia na emeryturę. W stolicy nawiązał kontakty ze środowiskiem tamtejszej inteligencji, bywał w kręgach profesorskich, publikował prace z zakresu literatury i paremiografii. Współpracował z wydawcami Encyklopedii Orgelbranda ${ }^{11}$, także udzielał się na innych polach, m. in. jako członek Warszawskiego Towarzystwa Dobroczynności ${ }^{12}$. Nie zapominał również o Białej, utrzymując kontakty z byłymi uczniami i znajomymi z Podlasia, gościł u siebie przybywających do Warszawy przyjaciół,

\footnotetext{
${ }^{9} \mathrm{O}$ czym pisał również wspomniany już Jan Gloger (tamże, s. 9-11).

${ }^{10}$ Inaczej opisuje stosunek Adama Bartoszewicza do powstania J. Flisiński. Zob. J. Flisiński, Szkoły bialskie w XVII-XX wieku. Monografia I Liceum Ogólnokształcacego im. J.I. Kraszewskiego, Biała Podlaska 1998, s. 119. Nie udało się jednak znaleźć źródeł na potwierdzenie tezy o sprzyjaniu powstaniu w pozostawionych przez Bartoszewiczów zbiorach. W zespole znajdują się natomiast dokumenty osobiste Adama Bartoszewicza, w których wyraźnie dystansuje się wobec powstania. Obok brudnopisów pism kierowanych do władz zwierzchnich i pisanych przez samego Bartoszewicza, w zbiorze występują dokumenty potwierdzające prawomyślność profesora szkoły bialskiej w okresie powstania listopadowego wystawione przez miejscowego proboszcza i burmistrza. Warto dodać, że tego rodzaju dokumentów wymagały władze szkolne - miały one na celu sprawdzenie czy też potwierdzenie „prawomyślności” kadry nauczycielskiej. Być może z tego powodu Adam Bartoszewicz starał się za wszelką cenę ukryć swoje sympatie wobec powstania. O czynnym udziale profesora w powstaniu nie wspominał jego wnuk Kazimierz, który, przy okazji edycji wspomnień dziadka, podawał jego życiorys.

${ }^{11}$ APŁ, Archiwum Bartoszewiczów, sygn. 791, k. 3 - list z zaproszeniem do współpracy z redakcją Encyklopedii Orgelbranda.

${ }^{12}$ Pracy w Towarzystwie oddawał się już po przejściu na emeryturę, aktywnie działając w Wydziale Opieki Sierot i Ubogich Dzieci (tamże, sygn. 745, k. 14,33).
} 
znajomych i byłych uczniów. Kazimierz Bartoszewicz, przy okazji opublikowania fragmentów pamiętnika swego ojca Juliana, pisał o tzw. „kole podlaskim”, jak nazywano krąg przyjaciół rodziny Bartoszewiczów -

kto przyjeżdżał do stolicy z Białej lub Łukowa lub ich okolicy - pisał wnuk Adama, Kazimierz - ten jak w dym szedł do Bartoszewiczów. Co więcej, wielu podlasiaków [sic!] również los przeniósł na bruk warszawski - i tu właśnie tworzyli owe przyjacielskie „Koło Podlaskie”"13.

Do grona tego należeli wspomniany Józef Ignacy Kraszewski (gdy tylko przebywał w Warszawie), bp Paweł Rzewuski ${ }^{14}$, pedagodzy: ks. Józefat Szczygielski $^{15}$, Karol Bystry ${ }^{16}$ czy Ludwik Koncewicz ${ }^{17}$. Do znajomych należeli również

${ }^{13}$ „Po powrocie do kraju [Juliana Bartoszewicza ze studiów w Petersburgu - przyp. I.F.] - pisał T. Kupczyński - znalazł się na powrót w rodzinnym kole, które z jednej strony skupiało około siebie wybitniejszych pedagogów warszawskich, z drugiej zaś było centrum Podlasian, z którymi rodzina szerokie posiadała stosunki" - T. Kupczyński, Bartoszewicz Julian (1821-1870), [w:] Wiek XIX. Sto lat myśli polskiej. Życiorysy, streszczenia, wyjątki, red. B. Chlebowski i in., t. 9, Warszawa i in. [1923], s. 209.

${ }^{14}$ Rzewuski Paweł (1804-1892) - urodził się w Telakach na Podlasiu, uczęszczał do szkoły w Białej, a następnie pobierał nauki w Warszawie, gdzie w 1827 r. otrzymał święcenia kapłańskie. Był biskupem nominatem, administratorem Archidiecezji Warszawskiej, biblistą i profesorem Akademii Duchownej w Warszawie. W 1865 r. za obronę interesów Kościoła w Królestwie Polskim został zesłany do Astrachania, gdzie przebywał do 1886 r. Po uwolnieniu zamieszkał w klasztorze w Krakowie, gdzie zmarł. B. Kumor, Rzewuski Pawet (1804-1892), [w:] Polski stownik biograficzny (dalej: PSB), t. 34, Kraków-Warszawa 1992-1993, s. 136-138.

${ }^{15}$ Szczygielski Jozafat (Józafat) (1805-1883) - urodził się we wsi Kobylany pod Międzyrzecem na Podlasiu, był uczniem szkoły w Białej. Naukę kontynuował w Warszawie, gdzie przyjął święcenia kapłańskie. Był rektorem Instytutu Głuchoniemych i Ociemniałych w Warszawie. Współpracował z biskupem Pawłem Rzewuskim, podobnie jak on został zesłany za „opozycyjną” postawę wobec władz rosyjskich. Początkowo trafił do Łaiszewa w guberni kazańskiej, a następnie kilka lat przebywał w Carewokokszajsku. Po powrocie z zesłania zamieszkał w Stoczku Arciechowskim, gdzie zmarł. Został pochowany na cmentarzu w Serocku. E. Niebelski, R. Prejs, Szczygielski Jozafat (1085-1883), PSB, t. 47, Kraków 2010-2011, s. 515-516; R. Żmuda, Działalność dydaktyczna i pisarska profesorów i wychowańców Warszawskiej Akademii Duchownej 1837-1867, Warszawa 1979, s. 231 i nast.

${ }^{16}$ Bystry Karol (1792-1861) - urodził się na Podlasiu, uczęszczał do szkoły w Białej, którą ukończył w 1812 r. Naukę kontynuował na Uniwersytecie Warszawskim. Pracował jako nauczyciel w Białej (1812-1823), a następnie w Łęczycy (do 1847 r.). W latach 1830-1832 pełnił tam funkcję rektora, a od 1833 r. inspektora. Nauczał łaciny, geografii i historii. A. Massalski, Stownik biograficzny. Nauczyciele szkót średnich rządowych męskich w Królestwie Polskim 1833-1862, Warszawa 2007, s. 98-99.

${ }^{17}$ Koncewicz Ludwik $(1791<1790$ ?>-1857) - urodził się na Podlasiu we wsi Łomazy, był synem proboszcza unickiego. Edukację rozpoczął w szkole wydziałowej w Białej, następnie ukończył studia na Wydziale Nauk i Sztuk Pięknych na Uniwersytecie Warszawskim. W latach 1810-1812 pracował w szkole w Białej, następnie zajął się nauczaniem prywatnym. Pracował w szkołach warszawskich, a od 1833 r. był dyrektorem Gimnazjum w Łukowie, skąd został usunięty w 1839 r. Nauczał języka polskiego i historii powszechnej (tamże, s. 208). Warto w tym miejscu dodać, że rodziny Bartoszewiczów i Koncewiczów były ze sobą zaprzyjaźnione od czasu pobytu w Łukowie. Szerzej - I. Florczak, Jak dawniej kochano - kobiety w życiu Juliana Bartoszewicza, [w:] Życie prywatne Polaków w XIX wieku, red. M. Korybut-Marciniak, M. Zbrzeźniak, Olsztyn 2013, s. 321 i nast. 
Józef Wieczorkowski ${ }^{18}$ i Aleksander Preyss ${ }^{19}$. Wszystkich wyżej wymienionych łączyła szkoła bialska - jedni byli uczniami Adama Bartoszewicza, inni zaś kolegami z grona pedagogicznego. Bartoszewiczów odwiedzali także członkowie podlaskich rodzin Welinowiczów, Wężyków, Kuszllów i Czermińskich ${ }^{20}$. Będąc na emeryturze Adam Bartoszewicz rozpoczął pisanie wspomnień dotyczących pobytu w Białej Podlaskiej, a także gromadził wypisy z ksiąg i czasopism dotyczące miasta i okolic. Zmarł w Warszawie 11 I 1878 r.

Julian Bartoszewicz urodził się w Białej Radziwiłłowskiej 21 I 1821 r. jako pierwsze dziecko Adama i Amelii. Naukę rozpoczął w szkole, w której pracował jego ojciec. W Białej nawiązał pierwsze przyjaźnie, które przetrwały także później, gdy Bartoszewiczowie przenieśli się do Warszawy. Mowa tu m. in. o zażyłości z Romanem Zmorskim, późniejszym poetą, który, podobnie jak młody Julian, edukację rozpoczął w szkole w Białej, a dalsze lata życia spędził w Warszawie - w stolicy obaj uczęszczali do gimnazjum na Lesznie. Zmorski, podczas nauki w Białej, w latach 1832-1833, wynajmował stancję w domu Adama Bartoszewicza. Nawiązana wówczas przyjaźń przetrwała przez kolejne lata, nawet po ucieczce poety z Królestwa Polskiego, a stosunki pomiędzy dwojgiem przyjaciół ze szkoły obrazuje ich wzajemna korespondencja ${ }^{21}$. W następnych latach, już po opuszczeniu Białej, Julian Bartoszewicz kontynuował naukę w szkołach w Łukowie i Warszawie. Od najmłodszych lat wykazywał talent literacki i zainteresowanie literaturą i historią. Wyróżniał się na tle innych uczniów, miał bardzo dobre wyniki w nauce - w związku z tym został stypendystą Królestwa Polskiego i jako taki rozpoczął studia na uniwersytecie w Petersburgu. Po ich ukończeniu i powrocie do Warszawy w 1842 r., podjął pracę jako nauczyciel w służbie państwowej. Wybór takiej samej ścieżki kariery zawodowej jak ojciec, nie do końca wynikał z zainteresowań Juliana Bartoszewicza - otóż jako stypendysta musiał odpracować określony czas w szkołach państwowych. Poza tym praca na

${ }^{18}$ Wieczorkowski Józef (1804-1883) - radca tajny, członek Rządzącego Senatu, prezes Sądu Apelacyjnego w Królestwie Polskim, inicjator i prezes Towarzystwa Osad Rolnych i Przytułków Rzemieślniczych, filantrop. Józef Wieczorkowski, „Kurier Warszawski” 1833, nr 50, s. 6.

${ }^{19}$ Preyss Aleksander (1814-1881) - syn rektora szkoły bialskiej Józefa, późniejszy prezes wydziału administracyjnego Warszawskiego Towarzystwa Dobroczynności i naczelnik wydziału Towarzystwa Kredytowego Ziemskiego (tamże, 1881, nr 276, s. 4).

${ }^{20}$ Nazwiska znajomych rodziny podaję za Kazimierzem Bartoszewiczem: Z notatnika pamiętniczego Juliana Bartoszewicza, opr. K. Bartoszewicz, „Przegląd Historyczny” 1912, t. 14, s. 129. W dzienniku Julian Bartoszewicz opisywał wizytę Karoliny z Kuszllów Wężykowej, dziedziczki Toporowa, matki Władysława Wężyka (1816-1848), podróżnika i autora Podróży po starożytnym świecie. Pewne dane dotyczące osób podane przez krakowskiego literata należało zweryfikować, co uczyniłam we wcześniejszych odwołaniach.

${ }^{21}$ E. Pieścikowski, Poeta - tułacz. Biografia literacka Romana Zmorskiego, Poznań 1964, s. 12. Wspomniane wyżej listy zostały wykorzystane w cytowanej biografii poety. 
etacie rządowym zapewniała stały, aczkolwiek niewielki dochód ${ }^{22}$. Jednocześnie rozwijał swe zainteresowanie historią i gromadzeniem źródeł historycznych. Pasję tę przejął od swego ojca, który przebywając jeszcze w Białej Podlaskiej wzbogacał swój księgozbiór, ratując stare księgi i rękopisy od zniszczenia ${ }^{23}$. Podobnie jak on dokonywał niezliczonych wypisów ze źródeł historycznych - miały mu służyć do wytężonej pracy naukowej. Obok pracy zarobkowej i naukowej, Julian Bartoszewicz zajmował się redagowaniem czasopism warszawskich, m.in. „Dziennika Warszawskiego” i jego późniejszej kontynuacji, czyli „Kroniki Wiadomości Krajowych i Zagranicznych". Publikował też artykuły w wielu periodykach w zaborze rosyjskim i poza jego granicami. Spod jego pióra wyszło wiele prac historycznych, biograficznych, ale także zarys dziejów literatury polskiej czy próba podsumowania polskiego dorobku historiograficznego pod tytułem Nowa epoka literatury historycznej polskiej ${ }^{24}$. Poglądy na rolę nauki historycznej, metodę pracy naukowej oraz dorobek historiograficzny Juliana Bartoszewicza przedstawili m.in. Jerzy Maternicki ${ }^{25}$ i Stefan Wrzosek ${ }^{26}$, zgadzając się, że był przedstawicielem nurtu antykwarystycznego $\mathrm{w}$ historii, a jego prace charakteryzowała drobiazgowość i atomistyczny faktografizm. Bogatej wiedzy towarzyszyło lekkie pióro, dzięki czemu historyk miał szerokie grono sympatyków w Królestwie Polskim i poza jego granicami. Zdobył też uznanie warszawskiego środowiska naukowego, stając się jednym z autorytetów epoki międzypowstaniowej ${ }^{27}$. Zmarł przedwcześnie w Warszawie, 5 XI 1870 r. w wieku 49 lat.

Kazimierz Bartoszewicz, syn Juliana był ostatnim właścicielem archiwum rodzinnego przed przekazaniem go do Łodzi. Urodził się w Warszawie, 19 XI 1852 r. Do szkoły uczęszczał w Warszawie, gdzie w czerwcu 1869 r. ukończył 7 - klasowe II Gimnazjum. Następnie rozpoczął studia w Cesarskim Uniwersytecie Warszawskim, jednakże po roku nauki (1871 r.) przeniósł się do Krakowa, aby podjąć naukę na Wydziale Prawa Uniwersytetu Jagiellońskiego, a następnie

${ }^{22}$ Szerzej na temat kariery nauczycielskiej Juliana Bartoszewicza: I. Florczak, Nauczyciel w stużbie państwowej. Między poczuciem obowiazku a własnymi aspiracjami. Przypadek Juliana Bartoszewicza (1821-1870), [w:] Między irredenta a kolaboracja. Ugoda, legalizm, lojalizm. „Dusza urzędnika” - ludzie i ich kariery, red. A. Szmyt, Olsztyn 2015, s. 51 i nast.

${ }^{23} \mathrm{O}$ czym pamiętał i wspominał właśnie Józef Ignacy Kraszewski.

${ }^{24}$ W cyklu artykułów recenzyjnych publikowanych w „Bibliotece Warszawskiej” w latach 1850-1853 J. Bartoszewicz dokonał przeglądu polskiej literatury historycznej ukazującej się na ziemiach polskich od lat 30. XIX w. Szerzej - I. Florczak, Julian Bartoszewicz jako wspótpracownik „Biblioteki Warszawskiej”, „Rocznik Łódzki”, t.61, 2014, s. 111.

${ }^{25}$ J. Maternicki, Julian Bartoszewicz (1821-1870), [w:] Historycy warszawscy ostatnich dwóch stuleci, red. A. Gieysztor, J. Maternicki i H. Samsonowicz, Warszawa 1986, s. 77-91.

${ }^{26}$ S. Wrzosek, Julian Bartoszewicz. Człowiek, dzieło, znaczenie, [w:] Intelektualiści rodem z Podlasia, red. J. Sekuła, Siedlce 1997, s. 126 i nast.

${ }^{27}$ Tenże, Juliana Bartoszewicza dzieło niemożliwe: ,przeliczyć do końca”, „Podlaski Kwartalnik Kulturalny" 1998, nr 4, s. 31. 
kontynuować ją na Wydziale Filozoficznym ${ }^{28}$. Po ukończeniu studiów pozostał w Galicji, gdzie zajmował się m.in. prowadzeniem księgarni, wydawaniem książek i czasopism. Pracę literacką rozpoczął już w 1867 r. i kontynuował ją aż do śmierci w 1930 r. Współpracował z wieloma czasopismami krakowskimi, lwowskimi i warszawskimi. $Z$ biegiem lat stał się cenionym literatem, znanym w środowisku naukowym Galicji. Wybierając niepewny zawód literata niemalże przez całe życie borykał się z problemami finansowymi. Był też wieloletnim radnym miejskim i aktywnym działaczem społecznym, jak również członkiem i założycielem wielu towarzystw, m.in. krakowskiego Towarzystwa Oświaty Ludowej, Koła Literacko-Artystycznego, Towarzystwa Gimnastycznego „Sokół”. Należał do Resursy Mieszczańskiej i Resursy Urzędniczej. W latach 1896-1899 był prezesem Związku Literackiego ${ }^{29}$. Od 1895 r. działał w Towarzystwie Szkoły Ludowej (TSL), będąc członkiem Zarządu Głównego, a w jego łonie członkiem komisji organizacyjnej i jej przewodniczącym ${ }^{30}$, a także w wielu innych organizacjach, które za cel stawiały w sobie szeroko rozumianą obronę polskości, a więc tradycji, języka, kultury i gospodarki. Stąd też wynikało zaangażowanie Bartoszewicza w powołanie do życia, a następnie uczestniczenie w pracach organizacji pod nazwą „Straż Polska”. Wspominam o tym dlatego, że stowarzyszenie organizowało wycieczki krajoznawcze do Królestwa Polskiego, a także na Litwę. Ich inicjatorem, głównym organizatorem i wreszcie przewodnikiem był właśnie Kazimierz Bartoszewicz. Trasa wycieczek był zróżnicowana, poprzez Warszawę i Lublin, aż do Wilna i Troków ${ }^{31}$. Niewykluczone, że trasa wiodła również przez ziemie Podlasia. Kazimierz Bartoszewicz z pewnością darzył sentymentem Białą Podlaską, gdzie przez wiele lat mieszkał dziadek wraz z rodziną i gdzie urodził się i dorastał jego ojciec. Okazją do odwiedzenia Białej był jubileusz 300-lecia powstania akademii bialskiej (1928 r.) - wówczas Bartoszewicz został zaproszony do udziału w uroczystościach, organizowanych przez specjalnie do tego celu utworzony komitet. Do Białej Podlaskiej zaprosił go wówczas dr Wacław Nartowski, dyrektor szkoły, z którym Bartoszewicz korespondował i wymieniał informacje dotyczące przeszłości szkoły i miasta. Warto wspomnieć, że był on członkiem honorowym komitetu organizującego jubileusz szkoły ${ }^{32}$. Zwrócenie się

\footnotetext{
${ }^{28}$ APŁ, Archiwum Bartoszewiczów, sygn. 1448, Dokumenty osobiste i szkolne Kazimierza Bartoszewicza 1863-1928, k. 17, 24.

${ }^{29}$ F. Ziejka, Zwiazek Literacki w Krakowie (1891-1899), „Zarządzanie w Kulturze” 2012, nr 13, z. 1, s. 78 .

${ }^{30}$ Z Zarządu Głównego, „Miesięcznik Towarzystwa Szkoły Ludowej” 1901, nr 4, s. 55; 1901, nr 5, s. 80 .

${ }^{31}$ APŁ, Archiwum Bartoszewiczów, sygn. 2805, k. 186, 188.

32 Pismo z prośbą o przyjęcie godności członka honorowego komitetu zostało wysłane do krakowskiego literata w listopadzie 1927 r. (tamże, sygn. 2821, k. 1). W teczce znajduje się również Program obchodów 300-lecia Gimnazjum Męskiego w Białej Podlaskiej i II zjazdu koleżeńskiego byłych wychowanków. Do kwestii przygotowań uroczystości powrócę w dalszej części tekstu.
} 
do krakowskiego redaktora z zaszczytną propozycją nie było przypadkowe - był bowiem wnukiem Adama i synem Juliana, którzy, jak wspomniano, zasłużyli się dla miasta i Podlasia. Zainteresowania badawcze Bartoszewicza skupiły się, także na dziejach Radziwiłłów i Białej na Podlasiu. Ostatnie lata życia Bartoszewicz spędził na porządkowaniu archiwum rodzinnego. Jego celem, wobec braku spadkobierców ${ }^{33}$, o czym była już mowa, było zapewnienie zgromadzonej kolekcji odpowiednich warunków przechowywania oraz udostępnienie jej szerokiemu gronu odbiorców. Stąd też wynikła decyzja przekazania materiałów do Łodzi, miasta, które nie posiadało jak dotąd cennych materiałów archiwalnych. Przed śmiercią literat zdążył sfinalizować rozmowy z reprezentującym Magistrat Miasta Łodzi, Przecławem Smolikiem i przekazać miastu część materiałów. Zmarł w samotności w Krakowie 20 I 1930 r. ${ }^{34}$

\section{Źródła do dziejów Podlasia w Archiwum rodziny Bartoszewiczów}

Zgromadzone materiały archiwalne związane $\mathrm{z}$ omawianym terenem, pochodzą z różnych okresów historycznych, dotyczą zarówno epoki staropolskiej jak też XIX i XX wieku. Materiały te możemy zasadniczo podzielić na kilka grup - pierwszą z nich będą dokumenty, które wiązały się z pobytem i działalnością Bartoszewiczów na Podlasiu, szczególnie zaś w Białej Podlaskiej, w której pobyt rodziny, jak wspomniano wyżej, był związany z pracą Adama Bartoszewicza w szkole wydziałowej w Białej. Drugą grupę stanowić będą materiały zgromadzone przez twórców archiwum, a odnoszące się do osób i miejscowości historycznie lub administracyjnie związanych z Podlasiem. Kolejną częścią omawianych archiwaliów są materiały wytworzone przez Juliana i Kazimierza Bartoszewiczów, będące tekstami historycznymi dotyczącymi przeszłości Podlasia. Do ostatniej grupy zaliczymy korespondencję twórców archiwum z mieszkańcami tych terenów, związanej też z gromadzeniem źródeł historycznych i badaniem przeszłości omawianego terytorium.

Zanim przejdziemy do opisu poszczególnych grup materiałów, należałoby zastanowić się w jaki sposób cenne rękopisy trafiały w ręce Bartoszewiczów. Część z nich stanowiły kopie (odpisy) ${ }^{35}$ wykonane przez samych Bartoszewiczów w czasie kwerend archiwalnych i podróży po kraju, podczas których znajdowali zapomniane i zaniedbane manuskrypty. Współpracowali także z innymi kolekcjonerami, wymieniając się dokumentami, lub też dokonując wypisów z użyczonych

${ }^{33}$ Żona i wszystkie jego dzieci zmarły wcześniej, dlatego też nie miał spadkobiercy. Materiały pozostawione po synach, którzy, podobnie jak ojciec, byli literatami, stały się częścią omawianego archiwum.

${ }^{34}$ P. Smolik, Bartoszewicz Kazimierz (1852-1930), PSB, t. 1, Kraków 1935, s. 327.

${ }^{35}$ Sporządzanie odpisów ze źródeł było w tym czasie bardzo powszechne. Wypisy robiono nie tylko z dokumentów, ale także z dzieł naukowych, a także dzieł literackich - powodem był powszechny brak dostępu do książek, a także ich wygórowane ceny. 
im dokumentów ${ }^{36}$. Warto dodać, że Julian Bartoszewicz, niekwestionowany w okresie międzypowstaniowym autorytet $\mathrm{w}$ zakresie badań źródłowych, na prośbę innych kolekcjonerów oceniał wartość historyczną odnajdywanych materiałów, porządkował zbiory i archiwa prywatne, wykonując przy tym niezliczone ilości wypisów dla własnych celów naukowych. Otrzymywał też pewne dokumenty na własność. Warto w tym miejscu wspomnieć o podróży Juliana Bartoszewicza do Jeżewa, siedziby Glogerów, gdzie warszawski historyk porządkował m. in. papiery hetmana Jana Klemensa Branickiego znalezione na Podlasiu przez syna gospodarza domu Zygmunta ${ }^{37}$. Warto dodać, że wyprawę na Podlasie opisał prawdopodobnie Julian Bartoszewicz w artykule pt. Wędrówki po kraju. Wyprawa $w$ Tykocińskie, którego brudnopis znajduje się w omawianym archiwum ${ }^{38}$. Opisanie wrażeń z podróży do Szepietowa było pretekstem do opowieści o ziemiach, ludziach i wydarzeniach historycznych z nimi związanych. Być może, część materiałów, które znajdują się obecnie w zasobie Archiwum Bartoszewiczów pochodzi właśnie z porządkowanych przez historyka fragmentów archiwum białostockiego hetmana Branickiego ${ }^{39}$. Wiele materiałów otrzymał Julian Bartoszewicz także w darze od czytelników i sympatyków jego talentu literackiego, a także od innych badaczy przeszłości. W tym czasie, szczególnie w okresie międzypowstaniowym, szczególnie ważne dla utrzymania tożsamości narodowej stało się odkrywanie pamiątek historycznych, a więc wszelkich pozostałości po przodkach. Szeroką

${ }^{36}$ Przykładem ilustrującym ten stan rzeczy będzie wymiana źródeł pomiędzy warszawskim historykiem i Zygmuntem Glogerem. Zob. Listy Juliana Bartoszewicza, [w:] Księga pamiatkowa na uczczenie setnej rocznicy urodzin Adama Mickiewicza (1798-1898), t. 1, Warszawa 1898, s. 115.

${ }^{37}$ Do Jeżewa wyjeżdżał Julian Bartoszewicz co najmniej dwukrotnie - w okresie letnim 1869 i 1870 r. na zaproszenie Zygmunta Glogera, który zgromadziwszy źródła z okolic potrzebował „fachowej” pomocy w ich porządkowaniu, ale też w rozpoznaniu wartości. Mowa tu o dokumentach pochodzących z tzw. archiwum białostockiego Jana Klemensa Branickiego (1689-1771), hetmana wielkiego koronnego, przechowywanym do początków XIX w. w rezydencji rodzinnej w Białymstoku. Po sprzedaży miasta rządowi pruskiemu, archiwum zostało wywiezione w części do Choroszczy i do klasztoru ojców bernardynów w Tykocinie, a następnie, w wyniku zaniedbań i likwidacji klasztoru w Tykocinie, uległo rozproszeniu i dalszemu podziałowi. T. Komorowska, Gloger. Opowieść biograficzna, Warszawa 1985, s. 62-64. Część spuścizny przechowywana w Choroszczy trafiła do archiwum hr. Potockiego w Rosi i obecnie jest przechowywana w AGAD pod nazwą Archiwum Roskiego. Pozostałe w Tykocinie materiały od zniszczenia uratował właśnie Zygmunt Gloger. Część tych materiałów sprzedał potem Annie Branickiej, żonie Ksawerego - dziś przechowywane w AGAD, stanowią część zbioru Anny z Potockich Ksawerowej Branickiej (http://archives.gov.by/ Radzivily/Data/PL_AGAD_338.xml, dostęp 8 XII 2015). Warto wspomnieć o tym, że przechowywane $\mathrm{w}$ archiwum hetmańskim listy zostały przez Juliana Bartoszewicza zestawione i opatrzone przypisami. Rękopis jego dzieła pt. Listy Wojciecha Jakubowskiego do Jana Klemensa Branickiego hetmana wielkiego koronnego z lat 1758-1771 został wydany w 1882 r. jako siódmy tom serii Biblioteki ordynacji hr. Krasińskich, Muzeum Konstantego Świdzińskiego.

${ }^{38}$ APŁ, Archiwum Bartoszewiczów, sygn. 959.

${ }^{39}$ Mam tu na myśli np. korespondencję Jana Klemensa Branickiego (tamże, sygn. 247, 450), o której będzie jeszcze mowa. 
akcję „zbieracką” ogłoszono także w prasie, a jej inicjatorem był również Julian Bartoszewicz, który od 1851 r., jako redaktor „Dziennika Warszawskiego”, publikował nadsyłane przez czytelników do redakcji materiały źródłowe. Największy odzew na akcję warszawskiego historyka miał miejsce właśnie na Podlasiu i na dawnych kresach I Rzeczypospolitej ${ }^{40}$. Warto podkreślić, że pasja kolekcjonerska Bartoszewiczów była ukierunkowana na materiały, które miały być użyteczne do pracy naukowej, a ich zainteresowania badawcze były dość szerokie - stąd też wynika rozpiętość tematyczna i chronologiczna zgromadzonych źródeł.

Pierwszą grupą materiałów, która z pewnością wiąże się z dziejami oświaty na omawianym terenie będą akta o charakterze urzędowym, które powstały w wyniku działalności zawodowej Adama Bartoszewicza. Będą to więc dokumenty dotyczące pełnienia funkcji nauczyciela w Białej Podlaskiej (sygn. 733), czy też dokumenty osobiste, wśród których znajdziemy m. in. Historyczny opis $\dot{z y c i a}$ Adama Bartoszewicza, w tym opis pobytu w Białej Podlaskiej ${ }^{41}$, a także akta dotyczące nominacji na Marszałka Zgromadzenia Gminnego Okręgu Bialskiego z lat 1826-183042. Wśród jednostek archiwalnych kryje się księga, w której zostały opisane wydarzenia związane z działalnością szkół bialskich z lat 1789-182743. Trudno określić autora księgi - z racji okresu, którego dotyczy i miejsca, w archiwum łódzkim przyporządkowano ją do części archiwum związanej z Adamem Bartoszewiczem. Licząca 94 strony, księga zawiera opis dziejów szkoły i miasta, ale także informacje związane $\mathrm{z}$ ważnymi wydarzeniami $\mathrm{w}$ jej historii - a mianowicie wizyty generalne władz szkolnych, publiczne popisy uczniów czy też informacje dotyczące śmierci nauczycieli szkoły. Na marginesie warto wspomnieć, że w księdze został opisany przebieg uroczystości pogrzebowych Józefa Preyssa, dyrektora szkoły wydziałowej w Białej. Być może księga stanowi część wspomnianych już sylwów pozostawionych przez profesora szkoły bialskiej, które opisał jego wnuk Kazimierz w 1912 r. ${ }^{44}$ Podobne w treści materiały dotyczą działalności Adama Bartoszewicza w szkole w Łukowie (miejscowość przynależała w latach 30. XIX w. administracyjne do województwa podlaskiego). Do tej grupy archiwaliów zaliczymy również materiały osobiste Juliana Bartoszewicza z okresu uczęszczania do szkół bialskich i łukowskich.

\footnotetext{
${ }^{40}$ Szerzej na temat sposobów gromadzenia zbiorów przez Bartoszewiczów zob.: I. Florczak, Dokumenty dotyczące miast $i$ województw w Archiwum rodziny Bartoszewiczów - próba charakterystyki, „Przegląd Nauk Historycznych”, R.XII, 2013, nr 2, s. 225.

${ }^{41}$ APŁ, Archiwum Bartoszewiczów, sygn. 734.

${ }^{42}$ Tamże, sygn. 735. W jednostce znajdują się 3 dokumenty nominacji - dwa z roku 1826 i jeden z 1830 r. Ponadto znajdujemy tu instrukcję przysłaną Bartoszewiczowi przez Komisję Rządową Spraw Wewnętrznych i Policji w sprawie przewodniczenia obradom nauczycieli.

${ }^{43}$ Tamże, sygn. 750.

${ }^{44}$ K. Bartoszewicz, Silva rerum..., s. 237 i nast.
} 
Odrębną część zgromadzonych archiwaliów stanowią wypisy z ksiąg ziemskich i grodzkich podlaskich ${ }^{45}$. Księgi ziemskie i grodzkie będące wytworem kancelarii sądowych podlaskich działających do końca XVIII w., jeszcze w okresie staropolskim, a także później, z różnych powodów, ulegały zniszczeniom i rozproszeniu. Ten proces niestety był udziałem większości ksiąg na ziemiach polskich. Losy ksiąg ziemskich i grodzkich podlaskich opisał Michał Kulecki zwracając uwagę na kolejne wydarzenia, w wyniku których akta ulegały zniszczeniom. Autor nie określił daty przekazania akt do archiwum wileńskiego, odrzucił jednak tezę B. Sobola ${ }^{46}$, że zostały przekazane w roku 1887 wraz z innymi księgami z Archiwum w Lublinie, wskazując jednocześnie, że fakt wywiezienia ksiąg mógł mieć miejsce znacznie wcześniej. W drugiej połowie XIX w. (1852 r.) zostały przekazane do Centralnego Archiwum Wileńskiego ${ }^{47}$, gdzie pozostawały do 1915 r. W tym właśnie roku, podczas I wojny światowej, najstarszą część zasobu archiwum wileńskiego (akta wytworzone do końca XVIII w.), wraz z księgami z obszaru Podlasia, wywieziono w głąb Rosji, do Moskwy. Pozostałe w Wilnie akta w okresie międzywojennym zostały przekazane do Archiwum Akt Dawnych w Warszawie, gdzie spłonęły podczas powstania warszawskiego w $1944 \mathrm{r}$. Pozostałe w archiwach radzieckich akta podzielono na trzy części - pierwsza z nich została przekazana Białorusi i obecnie jest przechowywana w Narodowym Archiwum Historycznym w Mińsku, druga została przekazana Polsce, a część ksiąg pozostała w Moskwie. W połowie lat 60 . XX w. w wyniku akcji rewindykacyjnej część materiałów, wywieziona z Wilna, została przekazana państwu polskiemu i została umieszczona w Archiwum Głównych Akt Dawnych w Warszawie, gdzie pozostaje do dziśs ${ }^{48}$. Obecnie rozproszone akta te stanowią część zasobu archiwów polskich, białoruskich, ukraińskich i rosyjskich. W wyniku procesów historycznych księgi podlaskie zachowały się fragmentarycznie - część,

${ }^{45}$ Próby opisu stanu zachowania i losów ksiąg z omawianego terytorium podjął Michał Kulecki - Spuścizna aktowa sądów ziemskich i grodzkich województwa podlaskiego - źródto do dziejów tamtejszej szlachty, [w:] Drobna szlachta podlaska. Materiały sympozjum w Holnach Mejera, 26-27 maja 1989 roku, red. S.K. Kuczyński, Białystok 1991, s. 141-147.

${ }^{46}$ B. Sobol, Księgi sądowe z obszaru Podlasia, [w:] Archiwum Główne Akt Dawnych w Warszawie. Przewodnik po zespołach. I. Archiwa dawnej Rzeczypospolitej, red. J. Karwasińska, wyd. 2, Warszawa 1975, s. 185.

${ }^{47}$ M. Kulecki, Spuścizna aktowa ..., s. 144-145.

${ }^{48}$ W AGAD znajdują się obecnie Księgi grodzkie brańskie z lat 1550-1758 - 57 j.a.; Księgi ziemskie drohickie z lat 1515-1696, 19 j.a.,; Księgi grodzkie drohickie 1474-1744, 99 j.a.; księgi grodzkie goniądzkie 1668-1679, 3 j.a; Księgi grodzkie mielnickie z lat 1562-1596, 9 j.a.; Księgi ziemskie sokólskie z roku 1794, 1 j. a.; Księgi ziemskie suraskie z lat 1554-1705, 14. j.a. Ponadto w AGAD zachował się sumariusz Akt Ziemskich i Miejskich Podlaskich z lat 1842-1886 - M. Kulecki, Zespoty ksiąg sądów szlacheckich I instancji. Wprowadzenie ogólne, [w:] Archiwum Główne Akta Dawnych $W$ Warszawie. Informator o zasobie archiwalnym, red. D. Lewandowska, Warszawa 2008, s. 100, 170-171. Warto nadmienić, że od kilku lat trwa współpraca między archiwami, a w jej wyniku AGAD otrzymało skany i mikrofilmy dokumentów znajdujących się np. w archiwum w Mińsku. 
jak już wspomniano znajduje się w AGAD, a także w Archiwum Państwowym w Krakowie, gdzie trafiły zbiory Zygmunta Glogera, zawierające fragment zbioru Ignacego Kapicy Milewskiego, czyli sporządzone w początkach XIX w. wypisy z ksiąg grodzkich podlaskich. Pewne zbiory znajdziemy również w Archiwum Państwowym w Białymstoku, dokąd w 2008 r. przekazano kopie 500 ksiąg grodzkich i ziemskich z XVI w. (z Centralnego Archiwum Historycznego z Mińska). Materiały, które znajdujemy u Bartoszewiczów, przy braku lub znacznym rozproszeniu, właściwych akt ziemskich i grodzkich, zyskują na znaczeniu ${ }^{49}$, podobnie jak wypisy, które odnajdujemy w Archiwum rodziny Bartoszewiczów. Wypisy zostały sporządzone przede wszystkim w drugiej połowie XVIII i początkach XIX w., a dotyczą spraw z XVII-XVIII w. Niestety, są to pojedyncze wytwory kancelarii ziemskich i grodzkich podlaskich, które nie pozwalają na przeprowadzenie badań dotyczących struktury i działalności tamtejszych kancelarii. W niektórych przypadkach jednostka archiwalna zawierająca wypisy, składa z się kilku dokumentów - nie zawsze są one ze sobą powiązane tematycznie - często połączono ze sobą wytwory tej samej kancelarii. Przykładem mogą być poświadczone wypisy z ksiąg ziemskich drohickich pochodzące z XVI i XVII w. czy też odpisy uwierzytelnione akt $\mathrm{z}$ kancelarii grodzkiej w Brańsku ${ }^{50}$. Ekstrakty zostały sporządzone zgodnie z ówczesną praktyką kancelaryjną, podpisane przez pisarza i dodatkowo opatrzone środkiem uwierzytelniającym w postaci pieczęci opłatkowej i podpisem urzędnika, potwierdzającego zgodność kopii z oryginałem ${ }^{51}$. Wśród zgromadzonych archiwaliów przeważają wpisy wieczyste dotyczące spraw prywatnych, niewiele z nich to dokumenty ilustrujące życie publiczne, zdarzają się jednak oblaty z uchwałami sejmików ziemskich danej ziemi. Będą to m.in. kontrakty kupna-sprzedaży ${ }^{52}$, darowizny ${ }^{53}$, zamiany ${ }^{54}$. Obok aktów o charakterze wieczystym znajdziemy również dokumenty potwierdzające wpisy o charakterze czasowym, czyli np. umowy dzierżawy ${ }^{55}$. W archiwum znajdziemy też odpisy

\footnotetext{
${ }^{49}$ Por. M. Kulecki,. Spuścizna aktowa sądów..., passim.

${ }^{50}$ APŁ, Archiwum Bartoszewiczów, sygn. 91, sygn. 204.

${ }^{51}$ Zgromadzone w jednostce archiwalnej wypisy były opatrzone zwrotem legit Popławski. Jeden z dokumentów uwierzytelnił swym podpisem Kapica - można przypuszczać, że chodzi tu o Ignacego Kapicę-Milewskiego, archiwistę kancelarii w Brańsku, który na zlecenie Piotr Potockiego, robił kopie i odpisy z ksiąg grodzkich z terenu Podlasia i północno-wschodniego Mazowsza, które obecnie uważa się za najcenniejsze źródła do wyżej wymienionych terenów.

${ }^{52}$ APŁ, Archiwum Bartoszewiczów, sygn. 25.

${ }^{53}$ Tamże, sygn. 91.

${ }^{54}$ Tamże, sygn. 87 - wypis z ksiąg grodzkich drohickich - zamiana dóbr Lissowo, Narojczyce, Bryki i Czachary w powiecie Drohiczyn należące do Jana Sapiehy, wojewody witebskiego, kapitana bracławskiego, marszałka wielkiego Księstwa Litewskiego, na dobra Dubno należące do Leonarda Kossieńskiego, 13 XII 1511. O Iwanie (Janie) Sapiesze i zamianie wyżej wspomnianych dóbr zob. M. Michalewiczowa, Sapieha Iwan (zm.1517), PSB, t. 34, Wrocław i in. 1992-1993, s. 613-618.

${ }^{55}$ Tamże, sygn. 102 - wypis z ksiąg grodzkich bialskich - akt dotyczący wydzierżawienia dóbr Cieszymy Tomaszowi Płońskiemu przez Stanisława Parzeckiego i Annę Szczawińską z roku 1702.
} 
akt o charakterze publicznym i politycznym - będą to dokumenty, które możemy zaliczyć do źródeł do dziejów polskiego parlamentaryzmu, na różnych etapach jego funkcjonowania ${ }^{56}$. Szczególnie interesujące będą źródła będące odzwierciedleniem sprawowanego przez sejmiki szlacheckie zarządu w ziemi lub województwie, ale także stanowiska szlachty wobec najważniejszych wydarzeń w państwie. Sytuacji politycznej i ekonomiczne na ziemiach polskich dotyczyła np. uchwała sejmiku ziemi bialskiej z 9 I 1716 r. $^{57}$ Innego rodzaju źródłami będą mowy sejmowe posłów z województwa podlaskiego wygłaszane podczas sejmów walnych i konfederackich ${ }^{58}$, które obrazują oczekiwania i stanowisko polityczne szlachty z tego województwa. Warto wspomnieć, iż źródła do dziejów parlamentaryzmu polskiego stanowią część silva rerów, zgromadzonych przez Bartoszewiczów. Interesujące materiały zawiera księga ułożona przez Kazimierza Szepietowskiego, w której zgromadził on źródła historyczne do dziejów parlamentaryzmu z okresu Księstwa Warszawskiego i Królestwa Polskiego. W liczącej ok. 700 kart księdze odnajdziemy materiały związane $\mathrm{z}$ funkcjonowaniem systemu przedstawicielskiego $\mathrm{w}$ województwie podlaskim (mowa tutaj również o terytorium województwa podlaskiego z okresu Królestwa Polskiego) jak i również z działalnością posła tykocińskiego Józefa Szepietowskiego ${ }^{59}$.

Warto też wspomnieć, o źródłach o charakterze gospodarczym, a mianowicie o oryginalnych kwitach podymnego wystawionych w latach 1776-1794 przez kancelarie w Drohiczynie, Tykocinie i Bielsku, podające nie tylko miejsce dokonania zapłaty, lecz również kwotę, którą należało wnieść do Skarbu Koronnego ${ }^{60}$.

Wśród zgromadzonej korespondencji znajdują się listy Jana Klemensa Branickiego, zarówno skierowane do niego, jak i przez niego napisane. Być może pochodziły ze wspomnianego już archiwum białostockiego wielkiego hetmana koronnego, którego część, o czym już była mowa, ocalił od zniszczenia Zygmunt Gloger ${ }^{61}$.

Osobną część spuścizny Bartoszewiczów stanowią materiały wytworzone w wyniku działalności naukowej i literackiej twórców archiwum. Artykuły i prace monograficzne Bartoszewiczów powstawały w oparciu o zgromadzone

\footnotetext{
${ }^{56}$ Szerzej: I. Florczak, Źródła do dziejów polskiego parlamentaryzmu w Archiwum rodziny Bartoszewiczów, [w:] Conventa et parlamenta. Studia i szkice z dziejów parlamentaryzmu, red. T. Matuszak, Piotrków Trybunalski 2015, s. 111-123.

${ }^{57}$ APŁ, Archiwum Bartoszewiczów, sygn. 204, k. 6-11.

${ }^{58}$ Tamże. Dla przykładu: Mowa Wacława Jeruzalskiego podkomorzego ziemi bielskiej na sejmie konfederackim warszawskim w 1705 r. (sygn. 507, k. 23); Mowa Józefa Markowskiego, stolnika mielnickiego i posła podlaskiego na sesji sejmowej w dniu 17 X 1776 (sygn. 513, k. 71-72).

${ }^{59}$ Tamże, sygn. 534.

${ }^{60}$ Tamże, sygn. 116.

${ }^{61}$ Tamże, sygn. 450 - list Krystyny Rozdrażewskiej w sprawie spadku po Zofii Koniecpolskiej (b.d.); sygn. 247 - List Jana Klemensa do wojewody kijowskiego Franciszka Salezego Potockiego z 29 III 1762 zawiera autograf i pieczęć Branickiego, wojewody krakowskiego i hetmana wielkiego koronnego; sygn. 121 - List J.K. Branickiego do Teodora Wessla, Białystok 4 XII 1763).
} 
w archiwum źródła. Monografię pt. Zamek bialski (dzieje miasteczka, obrazy z życia magnatów, akademia bialska) napisał Bartoszewicz jeszcze w 1849 r., jednak nie została ona wówczas wydana. Fragmenty, dotyczące lat 1760-1762, ukazały się w $1858^{62}$. Pierwszy raz w całości ukazała się w „Przeglądzie Naukowym i Literackim" w 1880 r., natomiast rok później we Lwowie pracę wydano jak samoistny druk. Po raz kolejny ukazała się w serii „Biblioteki dzieł wyborowych” w 1914 r. (t. 829 i 830). Zanim jednak opisane przez warszawskiego historyka dzieje Białej, a przy okazji także dzieje Radziwiłłów, ukazały się w całości, autor publikował mniejsze prace w periodykach. Artykuły te znalazły się w części archiwum zawierającej prace Juliana Bartoszewicza ${ }^{63}$.

Zainteresowania losami przedstawicieli rodu Radziwiłłów przejął syn historyka, Kazimierz. Spośród bogatego dorobku krakowskiego literata warto zwrócić uwagę na monografię poświęconą tej rodzinie. Wydana drukiem w 1928 r. praca dotyczy losów ważnych w dziejach rodu postaci, których koleje, jak wiadomo, były związane ze wschodnimi kresami I Rzeczypospolitej, w tym również z Białą. Maszynopis odnajdujemy $\mathrm{w}$ zasobie archiwum rodziny, wraz z poprawkami naniesionymi przez literata. Przy okazji Bartoszewicz gromadził teksty innych autorów dotyczące wyżej wspomnianej problematyki, m.in. artykuły historyka Jerzego Mycielskiego, ukazujące się w „Czasie” w cyklu „Radziwiłłowie”, które podczas porządkowania papierów, zostały przyporządkowane do tej samej jednostki. Wśród materiałów pozostawionych przez Kazimierza Bartoszewicza znajdziemy prace związane z przygotowaniem do druku pamiętnika mieszczanina podlaskiego ${ }^{64}$. W archiwum łódzkim pod sygnaturą 1979 (przed konkordancją 932) odnajdujemy tekst pamiętnika, wraz z uwagami i notatkami Bartoszewicza, przygotowującego tekst do druku. Po raz pierwszy pamiętnik ukazał się w „Nowej Reformie" latem 1917 r., rok później został wydany jako samoistny druk ${ }^{65}$. Kwestię autorstwa i wiarygodności owych wspomnień omówił Janusz Tazbir. Według historyka, opublikowane wspomnienia Rocha Sikorskiego stanowią popularne źródło wiedzy o Podlasiu na przełomie XVIII i XIX w. i są chętnie wykorzystywane przez badaczy, jednakże analiza treści i informacji o autorze, dostarczonych przez krakowskiego redaktora nie jest przekonująca, tym bardziej, że wydawca pamiętnika nie wyjaśnił, w jaki sposób wszedł w posiadanie pamiętnika, co stanowiło główny zarzut recenzentów wobec Bartoszewicza ${ }^{66}$.

${ }^{62}$ J. Bartoszewicz, Wyjątek z dzieła: Zamek bialski, „Księga świata”, Warszawa 1858, cz. 1-2, s. $11-18$.

${ }^{63}$ APŁ, Archiwum Bartoszewiczów, J. Bartoszewicz, Przestroga o zamiarach założyciela w ustanowieniu Kollegium, czyli osady akademickiej w Białej Książęcej, sygn. 997.

${ }^{64}$ Tamże, sygn. 1979. Pamiętnik ten ukazał się w Krakowie pod nazwą ,Lyki” $i$,,kołtuny”. Pamiętnik mieszczanina podlaskiego (1790-1816).

${ }^{65}$ J. Tazbir, Kto byt autorem ,tyków” i „, kottunów”?, [w:] Cudzym piórem... Falsyfikaty historyczno-literackie, Poznań 2002, s. 121-122.

${ }^{66}$ Tamże, s. 124-125. 
Z bogatej korespondencji twórców archiwum, zgromadzonej w zespole, warto odnotować listy Zygmunta Glogera do Juliana i Kazimierza Bartoszewiczów ${ }^{67}$ czy też zbiór listów Wacława Nartowskiego, dyrektora gimnazjum państwowego im. J.I. Kraszewskiego w Białej Podlaskiej do Kazimierza Bartoszewicza ${ }^{68}$. W wielu przypadkach trudność sprawia zidentyfikowanie autora i jedynie treść listów, pozwala na twierdzenie, że nadawca był mieszkańcem Podlasia. Przesyłano Bartoszewiczom, szczególnie Julianowi znalezione przypadkiem bardzo cenne materiały, lub też odpisy własnych akt rodzinnych, często w nadziei ich wydrukowania ${ }^{69}$.

Archiwum rodziny Bartoszewiczów stanowi bogaty zbiór źródeł archiwalnych z różnych okresów historycznych, różnorodnych zarówno pod względem tematycznym, geograficznym, jak i pod względem formy ${ }^{70}$. Wiele z nich dotyczy ziem województwa podlaskiego zarówno w jego granicach z okresu I Rzeczypospolitej, jak i w okresie porozbiorowym. Ich mnogość nie pozwala na wyczerpujące

${ }^{67}$ Gloger, któremu imponował dorobek naukowy i pracowitość warszawskiego historyka, starał się pomóc Bartoszewiczowi w objęciu Katedry Historii Polski w 1869 r. Pilnował „sprawy” na miejscu, czyli w Krakowie, a w listach przekazywał Bartoszewiczowi wieści i informacje dotyczące rozwoju sytuacji. Przy tej okazji, jako Królewiak, wytykał wady Polakom z Galicji (APŁ, Archiwum Bartoszewiczów, sygn. 1338, k. 2-13). List do Kazimierza Bartoszewicza dotyczył kwestii związanych z wydaniem prac jego ojca (tamże, sygn. 3043, k. 1-6).

${ }^{68}$ Tamże, sygn. 3035. Korespondencja obejmuje lata 1927-1929 i wiąże się z przygotowaniami do uczczenia 300-lecia szkoły bialskiej. Obok spraw związanych z organizacją uroczystości i zjazdu absolwentów gimnazjum dotyczyła poszukiwania materiałów dotyczących wyżej wspomnianej placówki. Kazimierz Bartoszewicz przesyłał również dyrektorowi Nartowskiemu kopie i rękopisy dotyczące Białej Podlaskiej i Akademii, które znajdowały się w jego posiadaniu. Ponadto dr Wacław Nartowski informował o postępach w pracach nad wydaniem dzieła krakowskiego literata pt. Dawna Biała na Podlasiu. Dzięki listom możemy także prześledzić zaangażowanie Kazimierza Bartoszewicza w prace organizacyjne Komitetu Obchodu 300-lecia Gimnazjum Męskiego w Białej Podlaskiej. Wspomniana wyżej praca ukazała się w 1928 r. w ramach serii wydawniczej „Biblioteczka Bialska”. Warto dodać, że pierwszy numer serii stanowiła praca W. Nartowskiego pt. Karty z przeszłości Białej (wyd. Biała Podlaska 1927). Zapewne wymiana informacji i źródeł autora z Kazimierzem Bartoszewiczem była związana z przygotowaniem tejże monografii.

${ }^{69}$ Artykuły poruszające problematykę historyczną drukowane w „Dzienniku Warszawskim”, a potem w „Kronice Wiadomości Krajowych i Zagranicznych” cieszyły się dużym zainteresowaniem wśród czytelników. Tekst Zygmunta Kaczkowskiego o Teodorze Wesslu, podskarbim wielkim koronnym, w którym autor przedstawił podskarbiego w nieprzychylnym świetle, wywołał protest jego wnuka Michała. Przesłał on, na ręce Juliana Bartoszewicza archiwum dziadka, zawierające materiały do dziejów konfederacji barskiej. Warszawski historyk podjął próbę rehabilitacji Wessla, opierając się na dostarczonych mu dokumentach. Obecnie przekazane materiały stanowią część omawianego archiwum i stanowią odrębną jego część pod nazwą Tek Wessla. A. Rosenberg, Zbiory rękopiśmienne..., „Dziennik Zarządu miasta Łodzi” 1938, nr 2, s. 154-155.

${ }^{70} \mathrm{O}$ różnorodności form wspominam w tekście, ale warto wymienić jeszcze inne tj. sumariusze, inwentarze (zarówno w rozumieniu spisu majątkowego jak i pomocy archiwalnej), regesty dokumentów, spisy ludności, źródła narracyjne, a wśród nich dzienniki, kroniki, relacje, także utwory historiograficzne i wiele innych. 
przedstawienie w niniejszym tekście pełnego wachlarza zachowanych akt. Wśród nich znajdziemy źródła o tematyce politycznej, akta gospodarcze, akta dotyczące historii kościoła i zgromadzeń zakonnych, historii miast, województw, ziem, materiały do dziejów rodów i rodzin. Wymienione wyżej archiwalia mogą być przydatne do zbadania wielu problemów badawczych, w zakresie historii społecznej i politycznej Podlasia w okresie przedrozbiorowym, ale także w XIX i XX w.

Ilona Florczak

\section{SOURCES FOR THE HISTORY OF PODLASIE IN THE FAMILY BARTOSZEWICZ'ARCHIVE}

This article is based on records, which are part of archival holdings State Archive in Lodz. Bartoszewicz' family archive, stored in Lodz, contains a variety of thematically and chronologically different archival materials. Some part of them refers to history of Podlasie from the sixteenth to the early twentieth century. The collection of historical sources had been created by members of Bartoszewicz' family, mainly by Adam (1792-1878), Julian (1821-1870) and Kazimierz (1852-1930). They were collectors and well-known publicists. Julian Bartoszewicz was also historian, who was one of the authorities in the field of history and historical sources in the mid-nineteenth century. The text also shows what kind of archival sources about Podlasie can be found there and why and in what ways these documents found in this archive. 